\title{
Characteristics of dendroaspis natriuretic peptide and its receptor in streptozotocin-induced diabetic rats
}

\author{
BYOUNG HYUN PARK ${ }^{1 *}$, SUN YOUNG KIM ${ }^{2 *}$, SOO MI KIM ${ }^{2}$, \\ HYE JUNG $\mathrm{NOH}^{1}, \mathrm{CHONG} \mathrm{GU} \mathrm{CHO}^{1}$ and SUNG ZOO KIM ${ }^{2}$ \\ ${ }^{1}$ Department of Internal Medicine, Medical School, Wonkwang University, Iksan, Jeonbuk 570-749; \\ ${ }^{2}$ Department of Physiology, Medical School, Institute for Medical Sciences, Chonbuk National University, \\ Jeonju, Jeonbuk 561-180, Republic of Korea
}

Received April 4, 2014; Accepted January 15, 2015

DOI: $10.3892 / \mathrm{mmr} .2015 .3678$

\begin{abstract}
Dendroaspis natriuretic peptide (DNP) shares a functionally important sequence homology with other natriuretic peptides. However, the characteristics of DNP and its receptor in the context of diabetes remafin to be fully elucidated. In the present study, alterations in the plasma levels and tissue contents of DNP and the properties of its receptor in diabetic rats, induced by streptozotocin (STZ) injection, were investigated. The plasma levels of DNP were $90.01 \pm 4.12$ and $196.68 \pm 5.60 \mathrm{pg} / \mathrm{ml}$ in the control and STZ-induced diabetic rats, respectively. The tissue contents of DNP in the cardiac atrium, ventricle, renal cortex and inner medulla of the STZ-induced diabetic rats were also significantly increased compared with the control rats. Specific ${ }^{125}$ I-DNP-binding sites were located predominantly in the glomeruli and inner medulla of the rat kidney. In the glomeruli of the kidney, the apparent dissociation constants $\left(K_{\mathrm{d}}\right)$ of ${ }^{125}$ I-DNP in the control and STZ-induced diabetic rats were $0.41 \pm 0.03$ and $0.56 \pm 0.06 \mathrm{nM}$, respectively. The maximum binding capacities $\left(\mathrm{B}_{\max }\right)$ of ${ }^{125} \mathrm{I}$-DNP in control and STZ-induced diabetic rats were $2.98 \pm 0.21$ and $6.22 \pm 1.06 \mathrm{fmol} / \mathrm{mg}$ protein, respectively. However, no differences were observed in the apparent $K_{\mathrm{d}}$ and $\mathrm{B}_{\max }$ of ${ }^{125} \mathrm{I}$-DNP in the inner medulla of the kidney between the control and STZ-induced diabetic rats. In the glomerular and inner medullary kidney membranes, DNP stimulated the production of cyclic guanosine monophosphate (cGMP) in a dose-dependent manner. The magnitude of cGMP production in glomerular membranes was greater in the STZ-induced
\end{abstract}

Correspondence to: Professor Sung Zoo Kim, Department of Physiology, Medical School, Institute for Medical Science, Chonbuk National University, 20 Gungiro, Deokjin-Gu, Jeonju, Jeonbuk 561-180, Republic of Korea

E-mail: szkim@jbnu.ac.kr

${ }^{*}$ Contributed equally

Key words: dendroaspis natriuretic peptide, natriuretic peptide receptors, cyclic guanosine monophosphate, diabetes, rat diabetic rats, whereas the magnitude of cGMP production in the inner medullary membranes was lower in the STZ-induced diabetic rats compared with the control rats. These results indicated that STZ-induced diabetes modulate DNP and its receptor, and also suggested that modulation of the DNP system is involved in the renal function of diabetic animals via the intracellular domain of the kidney NP receptor.

\section{Introduction}

Since dendroaspis natriuretic peptide (DNP) was originally isolated from the venom of the green mamba snake, Dendroaspis angusticeps (1), several studies have been performed to investigate its function. In one previous study, DNP was revealed to exhibit sequence similarities with atrial, brain and C-type natriuretic peptides (ANP, BNP and CNP) (2). DNP has also been detected in mammalian and human tissues (2-4). Synthetic DNP has been observed to induce natriuresis and diuresis in dogs when administered intravenously $(3,5)$ and also result in dose-dependent decreases in blood pressure in dogs (6). The natriuretic peptide receptors (NPRs) for DNP have been reported to localize to the smooth muscle tissue of the human mammary artery (4); in addition, DNP has been observed to induce vasodilatation via the direct activation of these receptors (7). Our previous studies provided evidence that DNP exerts renal actions via the NPR-A subtype and demonstrated that DNP and its specific receptor are present in the kidneys of rabbits (8-10). Collectively, these results suggested that DNP has a physiological role in regulating the renal function of mammals by interacting with specific NPRs, which have a particular guanylyl cyclase (pGC) domain.

Diabetic nephropathy is known to result from the interaction of genetic factors with chronic hyperglycemia (11). Chronic hyperglycemia induces a markedly increased incidence of cardiovascular pathology, which leads to myocardial dysfunction, hypertension and renal failure (12). Diabetic renal failure is characterized by distinct alterations in the regulation of sodium and water balance (13). Additionally, ANP has been observed to affect the course of diabetic nephropathy by affecting afferent arteriolar dilatation and efferent arteriolar constriction within the glomerulus (14). Infusion of ANP has also been observed to increase the glomerular filtration 
rate, filtration fraction and extent of albuminuria in patients with type I diabetes (15). In addition, plasma ANP levels are augmented in streptozotocin (STZ)-induced diabetic animals and in patients with diabetic nephropathy $(13,16)$, and the ANP-specific receptor is also significantly altered in the kidneys of a diabetic animal model $(13,17,18)$. The cardiac mRNA expression levels of BNP and NPRs have been observed to increase in STZ-induced diabetic animals compared with controls $(12,19)$, whereas the cardiac mRNA expression of CNP decreased (12). Although several studies have examined the modulation of natriuretic peptides and their receptors during the development of diabetic nephropathy, the precise association between the DNP system and diabetes remains to be elucidated. The aim of the present study was to investigate whether the DNP system has a pathophysiological role in the development of diabetic renal abnormalities. The extent to which the plasma levels of DNP, the tissue contents of DNP and/or the properties of the DNP receptor were altered in STZ-induced diabetic rats was investigated.

\section{Materials and methods}

Animals. A total of 49 male Sprague Dawley rats (200-250 g; Orient Bio, DaeJeon, Korea) were used in the present study. The animals were maintained at $\sim 20^{\circ} \mathrm{C}$ with a constant humidity of $55 \%$ and acclimated to standard conditions. The animals were maintained on an libitum diet of standard chow and tap water, maintained at $22-23^{\circ} \mathrm{C}$ with a constant humidity of $55 \%$, and acclimated with a cycle of $12 \mathrm{~h}$ of light/darkness, as described previously (8). The present study was approved by the ethics committee of Chonbuk National University, Institute for Medical Science (Jeonju, Jeonbuk, Republic of Korea), according to the National Institutes of Health (Bethesda, MD, USA) guidelines.

Diabetes mellitus was induced with a single intraperitoneal injection of STZ ( $80 \mathrm{mg} / \mathrm{kg}$ body weight; Sigma-Aldrich, St. Louis, MO, USA). Hyperglycemia was assessed by measuring the fasting blood glucose level $48 \mathrm{~h}$ post-induction using a glucometer (Roche Diagnostics GmbH, Berlin, Germany). Each rat was placed in a metabolic cage to facilitate measurements of food and water intake, urine volume and urinary electrolyte excretions. The electrolyte concentrations of plasma and urine were measured using an electrolyte analyzer (NOVA 4; Nova Biomedical Corporation, Waltham, MA, USA).

Measurement of DNP. The animals were sacrificed under pentobarbital (30-40 mg/kg) stable anesthesia and by decapitation. The plasma DNP concentrations were determined, as previously described (8). Briefly, blood was collected and plasma samples were obtained by centrifugation at $10,000 \times \mathrm{g}$ for $10 \mathrm{~min}$ at $4^{\circ} \mathrm{C}$. To measure the DNP contents of the heart and kidney, these tissues were prepared as previously described (8). Briefly, the tissues were finely minced, boiled in $0.1 \mathrm{~N}$ acetic acid, containing protease inhibitor mixture, for $10 \mathrm{~min}$, homogenized and then centrifuged at $10,000 \mathrm{x}$ g for $10 \mathrm{~min}$ at $4^{\circ} \mathrm{C}$. The supernatants were then assayed for levels of DNP.

Radioimmunoassay of DNP. For the DNP radioimmunoassay, ${ }^{125} \mathrm{I}$-DNP was prepared using a modified chloramine-T method, as described previously (20). Synthetic DNP
(5 $\mu \mathrm{g} / 5 \mu 10.1 \mathrm{M}$ acetic acid; Peninsula Laboratories, elmont, CA, USA) was introduced into a vial containing $25 \mu 10.5 \mathrm{M}$ phosphate buffered saline, followed by the addition of $1 \mathrm{mCi}$ 125I-Na (Amersham International, Amersham, UK). Chloramine-T $(10 \mu \mathrm{g} / 10 \mu \mathrm{l})$ was added to the reaction vial, mixed gently and following a $30 \mathrm{sec}$ incubation, bovine serum albumin (BSA; $60 \mathrm{mg} / 200 \mu \mathrm{l}$ ) solution was added. Rabbit (polyclonal) anti-DNP antibody (Phoenix Pharmaceuticals Inc, CA, USA) did not have any cross-reactivity with the other natriuretic peptides (ANP, BNP, or CNP). The lyophilized samples were reconstituted in phosphate buffer $(\mathrm{pH} 7.4)$, containing $50 \mathrm{mM} \mathrm{NaCl}, 0.1 \%$ BSA, $0.1 \%$ triton $\mathrm{X}-100$ and $0.01 \%$ sodium azide. Following incubation with rabbit antiDNP antibody at $4^{\circ} \mathrm{C}$ for $24 \mathrm{~h}, 125 \mathrm{I}-\mathrm{DNP}$ (specific activity $1420 \mathrm{Ci} / \mathrm{mmol}$ ) was added to each reaction mixture and incubated at $4^{\circ} \mathrm{C}$ for a further $24 \mathrm{~h}$. The separation of the free form from the bound form was achieved by the addition of secondary antibody and the radioactive pellets were counted in a gammacounter (Packard, Meriden, CT, USA). Non-specific binding was $1 \%$. The $50 \%$ intercept was at $202.8 \pm 15.2 \mathrm{pg} /$ tube $(n=9)$. The intra-and inter-assay coefficients of variation were $3.6 \pm 0.6(n=9)$ and $8.6 \pm 2.6 \%(n=8)$, respectively $(8)$.

Autoradiographic binding of ${ }^{125} \mathrm{I}-\mathrm{DNP}$. To measure the autoradiographic binding of ${ }^{125} \mathrm{I}-\mathrm{DNP}$, the samples ( $\mathrm{n}=6$; kidney) were rapidly removed and snap frozen in liquid nitrogen. Sample sections were cut in a transverse plane using a cryostat, thaw-mounted on gelatin-chrom-alum-coated slides and dried in a desiccator overnight. ${ }^{125}$ I-DNP binding to sample sections was determined as previously described $(8,21)$. Briefly, the sections were washed with $150 \mathrm{mM} \mathrm{NaCl}$ and $0.5 \%$ acetic acid (pH 5.0) at room temperature for $10 \mathrm{~min}$ in order to remove endogenous DNP. The tissue sections were subsequently pre-incubated with $30 \mathrm{mM}$ phosphate buffer ( $\mathrm{pH} 7.2$ ), containing $120 \mathrm{mM} \mathrm{NaCl}$ and $1 \mathrm{mM}$ phenanthroline at room temperature for $8 \mathrm{~min}$. The tissue sections were incubated with $250 \mathrm{pM}{ }^{125} \mathrm{I}$-DNP in fresh pre-incubation buffer, containing $40 \mu \mathrm{g} / \mathrm{ml}$ leupeptin and $0.5 \% \mathrm{BSA}$ at room temperature for $60 \mathrm{~min}$. Following the incubation, the tissue sections were rinsed and washed with the pre-incubation buffer for $5 \mathrm{~min}$ at $4^{\circ} \mathrm{C}$. Subsequently, the tissue sections were rinsed three times with cold distilled water at $4^{\circ} \mathrm{C}$. Computerized microdensitometry analysis of autoradiograms was performed with a Leica Wild M420 microscope (Leica Microsystems, Vienna, Austria) (22).

Measurement of $p G C$ activity. The NP-mediated stimulation of cGMP production by activated pGC was measured by performing equilibrated radioimmunoassays of tissue supernatants, as described previously (23).

Statistical analysis. The results are expressed as the mean \pm standard error of the mean. Comparisons between groups were evaluated using Student's t-test and one-way analysis of variance. $\mathrm{P}<0.05$ was considered to indicate a statistically significant difference.

\section{Results}

General characteristics of STZ-treated rats. The general characteristics of STZ-treated rats and their age-matched 
Table I. Characteristics of the rats in the control and streptozotocin-induced DM groups.

\begin{tabular}{lcc}
\hline Characteristic & Control group & DM group \\
\hline Number & 16 & 33 \\
Blood glucose (mg/dl) & $118.91 \pm 2.78$ & $459.70 \pm 13.09^{\mathrm{b}}$ \\
Hematocrit (\%) & $45.94 \pm 0.90$ & $45.40 \pm 0.42$ \\
Urine volume (ml/day) & $25.87 \pm 1.49$ & $182.43 \pm 13.25^{\mathrm{b}}$ \\
Plasma sodium (mmol/l) & $141.74 \pm 0.72$ & $136.28 \pm 0.38^{\mathrm{a}}$ \\
Plasma potassium (mmol/l) & $7.16 \pm 0.12$ & $6.63 \pm 0.13^{\mathrm{a}}$ \\
Plasma chloride (mmol/l) & $100.33 \pm 0.28$ & $92.74 \pm 0.43^{\mathrm{a}}$ \\
Plasma osmolality (mOsm/kg) & $282.42 \pm 1.53$ & $271.86 \pm 0.89^{\mathrm{a}}$ \\
Urinary sodium excretion (mol/l/day) & $2.23 \pm 0.36$ & $4.34 \pm 0.33^{\mathrm{a}}$ \\
Urinary potassium excretion (mol/l/day) & $4.24 \pm 0.29$ & $6.25 \pm 0.39^{\mathrm{a}}$ \\
Urinary chloride excretion (mol/l/day) & $3.35 \pm 0.25$ & $7.75 \pm 0.34^{\mathrm{a}}$ \\
Urine osmolarity (Osm/l/day) & $22.03 \pm 1.62$ & $146.52 \pm 6.05^{\mathrm{b}}$ \\
\hline
\end{tabular}

Data are expressed as the mean \pm standard error of the mean. ${ }^{\mathrm{a}} \mathrm{P}<0.05$ and ${ }^{\mathrm{b}} \mathrm{P}<0.01$, vs. control group. DM, diabetes mellitus.

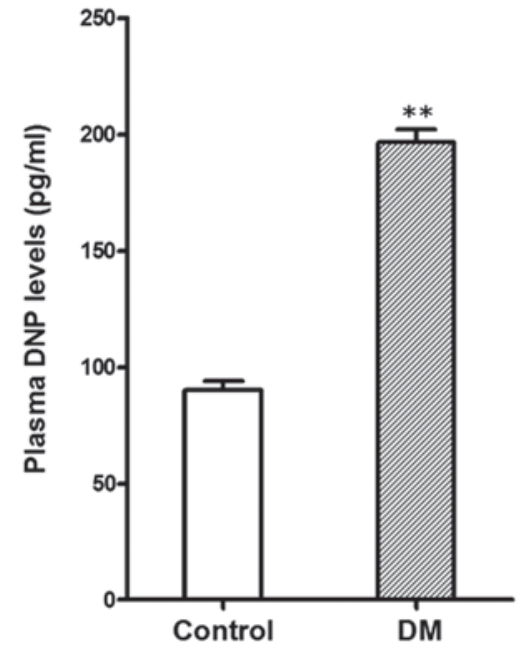

Figure 1. Plasma levels of DNP in control and STZ-induced diabetic rats Data are expressed as the mean \pm standard error of the mean.* $\mathrm{P}<0.01 \mathrm{vs}$. control. DNP, dendroaspis natriuretic peptide; STZ, streptozotocin; DM, diabetes mellitus.

controls are shown in Table I. Successful induction of diabetes in the STZ-treated rats was confirmed by the presence of severe hyperglycemia and significantly increased urine volumes compared with the untreated controls. No differences in hematocrit levels were observed between the control and STZ-treated rats. Plasma concentrations of sodium, potassium and chloride, in addition to osmolalities, in the STZ-treated rats were significantly less compared with those of the control rats. The analysis of renal function revealed that the urinary excretion of sodium, potassium and chloride by STZ-treated rats was significantly greater compared with that of the control rats. Notably, the urine osmolarity was significantly higher in the STZ-treated rats compared with the control rats.

Plasma levels and tissue contents of DNP. The levels of DNP in the blood, cardiac atria, cardiac ventricles, kidney cortex and kidney medulla were detected using a specific and sensitive radioimmunoassay. The plasma DNP levels of the control and STZ-treated rats were 90.01 $\pm 4.12(\mathrm{n}=18)$ and $196.68 \pm 5.60 \mathrm{pg} / \mathrm{ml}(\mathrm{n}=18)$, respectively. As shown in Fig. 1, the plasma levels of DNP were 2 -fold higher in the STZ-treated rats compared with the control rats.

The levels of DNP were also quantified in the cardiac atria, cardiac ventricles, renal cortex and renal medulla of each rat. The levels of DNP in the cardiac right atrium, cardiac left atrium and ventricles of the control rats $(n=18)$ were $1.59 \pm 0.12$, $1.70 \pm 0.25,0.48 \pm 0.11$ and $0.75 \pm 0.05 \mathrm{pg} / \mathrm{mg}$ wet weight, respectively. The levels of DNP in the kidney cortex and kidney medulla were $3.94 \pm 0.14$ and $2.06 \pm 0.35 \mathrm{pg} / \mathrm{mg}$ wet weight, respectively. As shown in Fig. 2, the DNP contents of these tissues in the STZ-treated rats were significantly increased compared with those of the control rats. However, these data did not reveal any significant association between the plasma DNP levels and the tissue DNP contents in either the heart or the kidney tissues.

Renal binding characteristics of ${ }^{125} I-D N P$. Specific ${ }^{125} \mathrm{I}-\mathrm{DNP}$ binding sites were identified in transverse kidney sections using in vitro receptor autoradiography. As shown in Fig. 3, the presence of specific and reversible binding sites of ${ }^{125} \mathrm{I}-\mathrm{DNP}$ in the kidney glomeruli and inner medulla were observed. The binding of ${ }^{125}$ I-DNP to the kidney was displaced entirely by $1 \mu \mathrm{M}$ unlabeled DNP, whereas no significant effect on the diffuse background binding was observed.

All the specific binding sites for ${ }^{125} \mathrm{I}-\mathrm{DNP}$ were more marked in the glomeruli compared with the inner medulla. In the control rats, the binding densities of ${ }^{125} \mathrm{I}-\mathrm{DNP}$ in the glomeruli and inner medulla of the kidney without acid washing were $1,735.21 \pm 11.15$ and $188.52 \pm 21.13 \mathrm{dpm} /$ unit area, respectively (Fig. 4). To determine whether the apparent modulation of a specific ${ }^{125} \mathrm{I}-\mathrm{DNP}$ binding site was caused by prior receptor occupancy by endogenous DNP, the kidney sections were washed with acetic acid solution prior to incubation with ${ }^{125}$ I-DNP. This acid washing, which removed the 
A

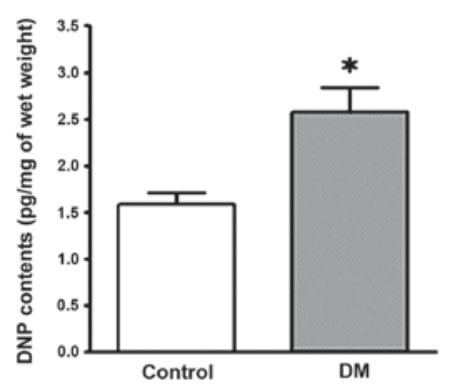

D

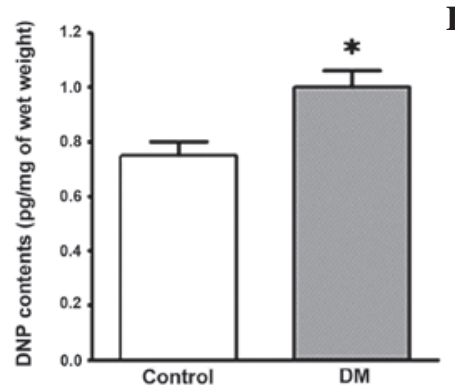

B

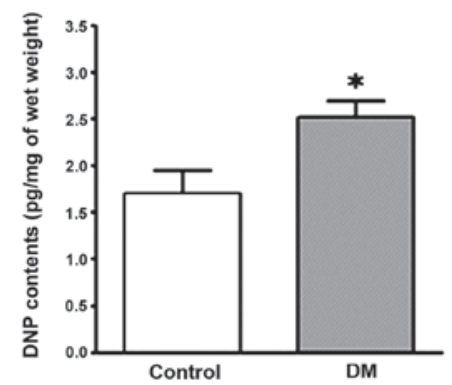

E

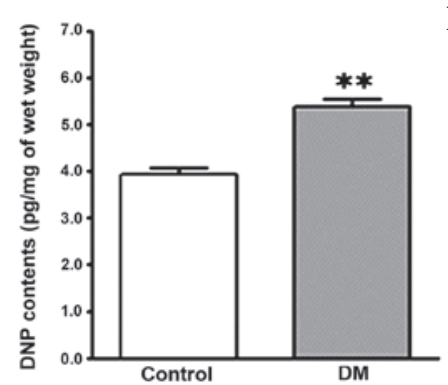

C

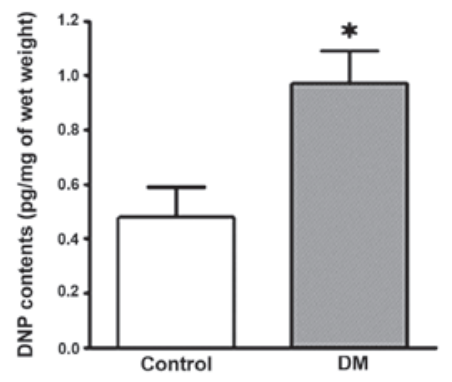

$\mathbf{F}$

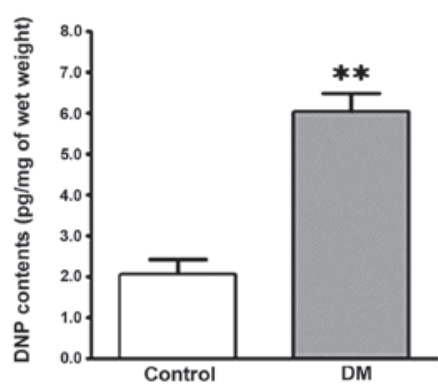

Figure 2. Quantities of DNP measured in the (A) right atrium, (B) left atrium, (C) right ventricle, (D) left ventricle, (E) renal cortex and (F) renal inner medulla in the control and STZ-induced diabetic rats. Data are expressed as the mean \pm standard error of the mean. ${ }^{*} \mathrm{P}<0.05$ and ${ }^{* * *} \mathrm{P}<0.01$ vs. control. $\mathrm{DNP}$, dendroaspis natriuretic peptide; STZ, streptozotocin; DM, diabetes mellitus.

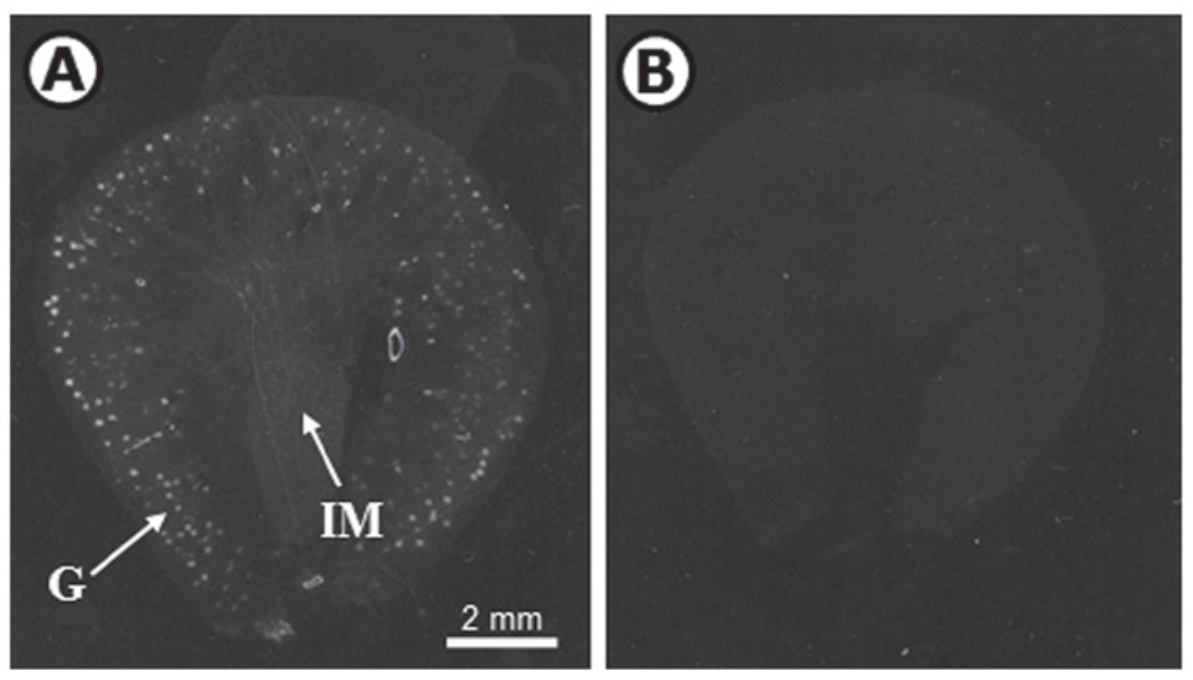

Figure 3. Dark-field photomicrograph of autoradiograms of rat kidney sections incubated in the presence of (A) ${ }^{125} \mathrm{I}-\mathrm{DNP}$ and (B) their adjacent sections incubated in ${ }^{125} \mathrm{I}-\mathrm{DNP}$ and an excess of unlabeled DNP $(1 \mu \mathrm{M})$ to remove nonspecific binding. Specific ${ }^{125} \mathrm{I}$-DNP binding sites appear as white silver grains in the glomeruli (G) and inner medulla (IM). DNP, dendroaspis natriuretic peptide.

endogenous DNP, markedly increased the specific binding densities of ${ }^{125} \mathrm{I}-\mathrm{DNP}$ to the renal glomeruli and inner medulla to 2,125.23 $\pm 17.40(\mathrm{P}<0.01)$ and 375.38 $\pm 39.25(\mathrm{P}<0.05) \mathrm{dpm} /$ unit area, respectively.

The results of the competitive inhibition analysis, which used unlabeled DNP to investigate the binding of ${ }^{125} \mathrm{I}-\mathrm{DNP}$ to the glomeruli and inner medulla of the kidney, were consistent with the presence of reversible binding sites for DNP, with uniform affinity, on the intrarenal structures. The specific binding of ${ }^{125}$ I-DNP to the kidney glomeruli and inner medulla was competitively inhibited by unlabeled DNP in a dose-dependent manner (Fig. 5). In the kidney glomeruli, the apparent dissociation constants $\left(K_{\mathrm{d}}\right)$ of ${ }^{125} \mathrm{I}-\mathrm{DNP}$ in the control and STZ-treated rats were $0.41 \pm 0.03$ and $0.56 \pm 0.06 \mathrm{nM}$, respectively. The maximal binding capacities $\left(\mathrm{B}_{\max }\right)$ of ${ }^{125} \mathrm{I}-\mathrm{DNP}$ in the control and STZ-treated rats were $2.98 \pm 0.21$ and $6.22 \pm 1.06 \mathrm{fmol} / \mathrm{mg}$ protein, respectively. In the inner kidney medulla, the apparent $K_{\mathrm{d}}$ of ${ }^{125} \mathrm{I}-\mathrm{DNP}$ in the control and STZ-treated rats were $0.25 \pm 0.01$ and $0.28 \pm 0.01 \mathrm{nM}$, respectively. The $\mathrm{B}_{\max }$ of ${ }^{125} \mathrm{I}-\mathrm{DNP}$ in the control and STZ-treated rats were $0.62 \pm 0.01$ and $0.61 \pm 0.06 \mathrm{fmol} / \mathrm{mg}$ protein, respectively. 
A

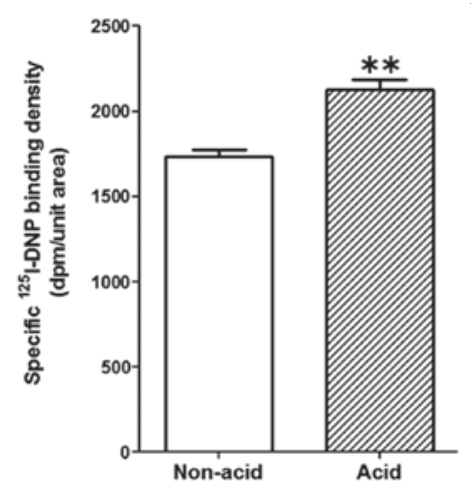

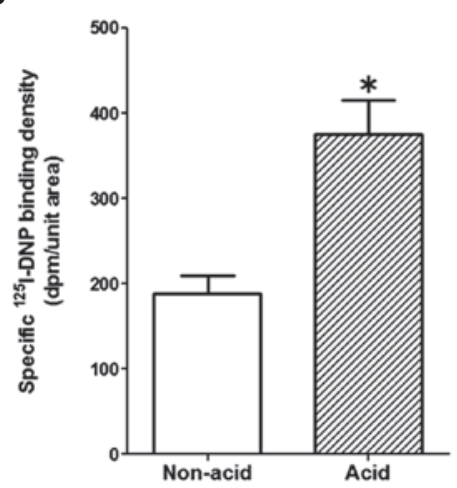

Figure 4. Effect of acid-washing on the specific binding densities of ${ }^{125}$ I-DNP in the (A) renal glomeruli and (B) inner medulla of control rats. Data are expressed as the mean \pm standard error of the mean. ${ }^{*} \mathrm{P}<0.05$ and ${ }^{* * *} \mathrm{P}<0.01$ for non-acidic washed vs. acidic washed specific ${ }^{125} \mathrm{I}$-DNP binding densities $(\mathrm{n}=6)$. DNP, dendroaspis natriuretic peptide.

A

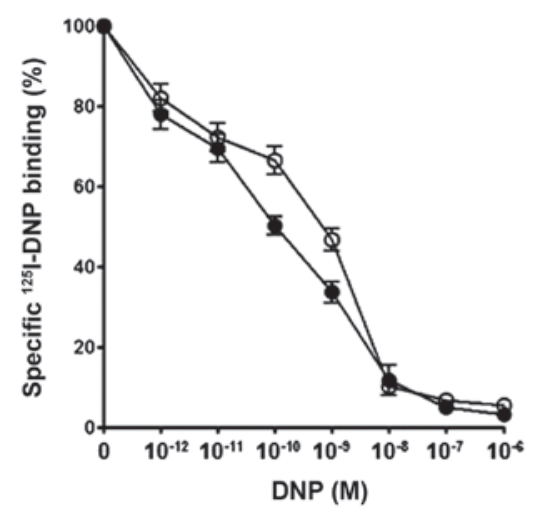

B

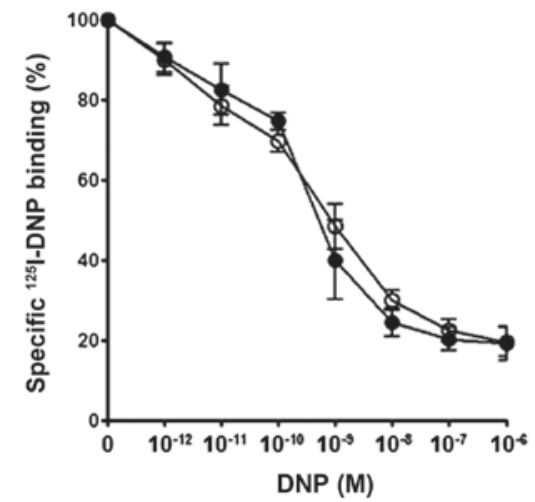

Figure 5. Competitive inhibition of the maximum specific binding of ${ }^{125} \mathrm{I}$-DNP by increasing the concentration of unlabeled DNP. Data are expressed as the mean \pm standard error of the mean and values are shown for the binding to the (A) renal glomeruli and (B) inner medulla in the (open circles) control and (filled circles) STZ-induced diabetic rats $(n=6)$. DNP, dendroaspis natriuretic peptide; STZ, streptozotocin.

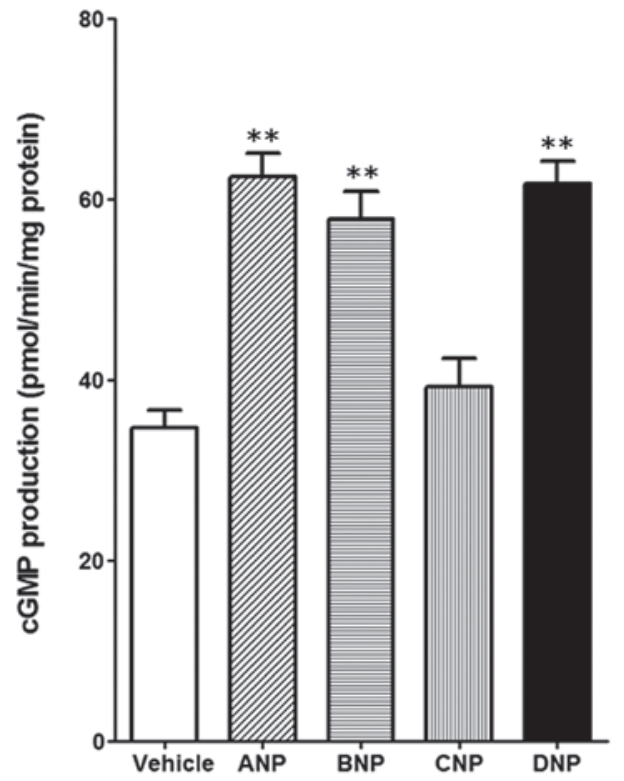

Figure 6. Production of cGMP in response to various natriuretic peptides (all $1 \mu \mathrm{M}$ ) by plasma membranes from the glomeruli and inner medulla of the rat kidney. Data are expressed as the mean \pm standard error of the mean. ${ }^{* * *} \mathrm{P}<0.01$ vs. vehicle group. cGMP, cyclic guanosine monophosphate; ANP, atrial natriuretic peptide; BNP, brain natriuretic peptide; CNP, c-type natriuretic peptide; DNP, dendroaspis natriuretic peptide.
cGMP production. The basal rates of cGMP production, which rely upon the activation of pGC, in the glomerular and inner medullary membranes in the control rats were $34.64 \pm 1.69$ and $42.35 \pm 3.45 \mathrm{pmol} / \mathrm{min} / \mathrm{mg}$ protein, respectively. By contrast, the addition of $1 \mu \mathrm{M}$ DNP to the glomerular membranes increased the production of cGMP $\sim 2$-fold above the basal level. The natriuretic peptides were ranked in the following order, according to their potency in stimulating cGMP production: $A N P \geq D N P \geq B N P>>C N P$ (Fig. 6). As shown in Fig. 7, the production of cGMP was stimulated in a dose-dependent manner by synthetic DNP. The dose-response curve of cGMP production in the glomerular membranes from the STZ-treated rats was significantly higher compared with the control rats, whereas the dose-response curve in the inner medullary membranes from the STZ-treated rats was slightly lower compared with the control rats.

\section{Discussion}

The present study examined the modulation of DNP and its specific receptor in STZ-induced diabetic rats with severe hyperglycemia. The successful induction of diabetes in the STZ-treated rats was first confirmed by observing certain changes in their general characteristics and comparing them 
A

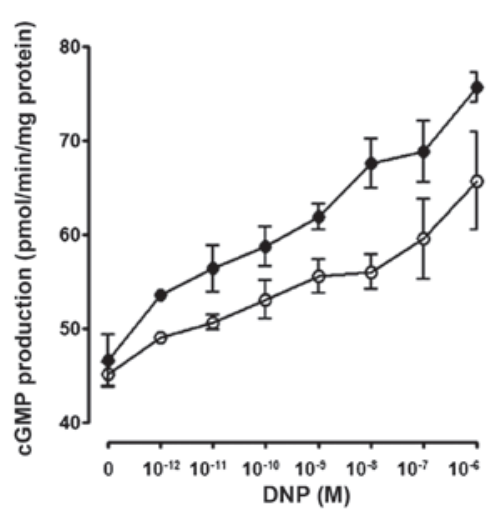

B

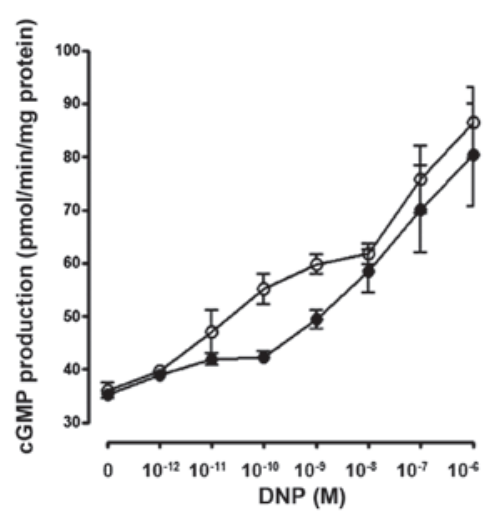

Figure 7. Dose-dependent cGMP responses stimulated by DNP in the renal glomerular (A) and inner medullary (B) membranes of the $\left(^{\circ}\right)$ control and (•) STZ-induced diabetic rats. cGMP, cyclic guanosine monophosphate; DNP, dendroaspis natriuretic peptide; STZ, streptozotocin.

with age-matched control rats (Table I). Briefly, the treatment of rats with STZ resulted in significantly elevated plasma glucose levels and significantly increased daily urine volumes, changes typical of type I diabetes. The plasma electrolyte compositions of the STZ-treated rats weer decreased after 2 weeks, whereas the urinary electrolyte excretions and osmolarities were significantly increased in the STZ-treated rats.

In diabetic animals and patients with diabetes, NPs and their specific receptors are altered, which suggests that they are important in the pathogenesis of diabetic renal abnormalities (24). The plasma levels of ANP in diabetic rats have been reported to be higher compared with those in age-matched controls (13). In addition, the mRNA expression levels of ANP and BNP have been observed to be upregulated in cardiac tissue from STZ-induced diabetic animals $(12,19,25)$. Acute hyperglycemia has also been found to stimulate the secretion of ANP in cardiac tissues (26). By contrast, the cardiac mRNA expression of CNP is decreased in STZ-induced diabetic rats (12). Although diabetes with hyperglycemia may potentially lead to alterations in cardiac and renal functions by stimulating the synthesis and secretion of natriuretic peptides, the precise association between DNP and the pathogenesis of diabetes remains to be elucidated. In the present study, the plasma levels and tissue contents of DNP in STZ-induced diabetic rats were significantly increased compared with the control rats. Thus, the cardiac and renal DNP contents were investigated, with the aim of identifying the predominant source of elevated plasma DNP levels in STZ-induced diabetic rats. Although the tissue contents of DNP in the cardiac atria, cardiac ventricles, renal cortex and renal medulla in the STZ-induced diabetic rats were significantly increased compared with those of the control rats, no association was observed between the plasma DNP levels and the tissue DNP contents of these organs. As DNP was originally identified in a reptilian species (1), the main organ responsible for the synthesis and/or secretion of DNP remains to be elucidated. Therefore, the present findings suggest that DNP may act as a local hormone to affect biological functions, and that DNP may modulate its own expression in pathological conditions, including diabetes.

The binding characteristics of specific ${ }^{125}$ I-DNP binding sites were also investigated using quantitative in vitro receptor autoradiography. In the present study, autoradiograms of rat kidney transverse sections revealed that specific ${ }^{125}$ I-DNP binding sites were localized predominantly in the glomeruli and the inner medulla. These intrarenal localizations of specific ${ }^{125}$ I-DNP binding sites were consistent with our previous data (8). In the present study, the binding characteristics of DNP to the NPRs in rat kidneys exhibited marked heterogeneity. The maximum specific binding density of ${ }^{125}$ I-DNP, which indicates the binding of a radiolabeled ligand in specific conditions, was significantly higher in the glomeruli compared with the inner medulla. Competitive inhibition analysis of the displacement of ${ }^{125} \mathrm{I}$-DNP with unlabeled DNP indicated that the binding affinities of ${ }^{125}$ I-DNP in the rat kidney glomeruli were marginally lower compared with those in the inner medulla, whereas the maximal binding capacities were significantly higher in the glomeruli compared with the inner medulla. These results suggested that the observed heterogeneity in the maximum specific ${ }^{125}$ I-DNP binding densities in the intrarenal structures is associated with differences in the properties of the receptor populations, rather than the binding affinities of the receptor molecules. As shown in Fig. 4, it was also observed that specific binding of ${ }^{125}$ I-DNP in the glomeruli and the inner medulla was significantly increased following removal of endogenous natriuretic peptides using an acidic wash. This finding suggests that rat intrarenal NPRs, which bind ${ }^{125} \mathrm{I}-\mathrm{DNP}$, are exposed to endogenous natriuretic peptides, including DNP, as in rabbit kidneys (8).

To the best of our knowledge, the present study is the first to demonstrate that the binding characteristics of ${ }^{125} \mathrm{I}$-DNP in the kidney are altered in STZ-induced diabetic animals. In rats with STZ-induced diabetes, the maximum binding capacities of ${ }^{125}$ I-DNP in the glomeruli were significantly increased compared with those in the control group, whereas the binding affinities of ${ }^{125} \mathrm{I}$-DNP to these structures were slightly decreased. However, the binding of ${ }^{125} \mathrm{I}$-DNP in the inner medulla was not significantly different between the control and STZ-induced diabetic rats. These results suggested that the number of NPRs for DNP in the kidney of STZ-induced diabetic rats is altered predominantly in the glomeruli. Previous studies $(17,18)$ have investigated the binding characteristics of NPRs in the intrarenal structures of STZ-induced diabetic rats; these studies used ${ }^{125} \mathrm{I}$-ANP as a radiolabeled ligand. In these studies, the maximum binding capacities of ${ }^{125} \mathrm{I}$-ANP to the glomeruli in STZ-induced 
hyperglycemic diabetic rats were significantly decreased in comparison with control or normoglycemic diabetic rats, whereas those to the inner medulla remained unchanged. No significant difference was identified in the binding affinities of ${ }^{125} \mathrm{I}$-ANP to the glomeruli and the inner medulla between control and STZ-induced diabetic rats. Considering the differences that have been observed between the binding properties of ${ }^{125} \mathrm{I}$-ANP and ${ }^{125} \mathrm{I}$-DNP, it is hypothesized that NPRs may be modulated by the expression of different natriuretic peptides during the pathogenesis of diabetes.

NPRs are classified into three subtypes: NPR-A, NPR-B, and NPR-C. NPR-A and NPR-B receptors each consist of two monomeric proteins, with a combined molecular mass of 120-140 kDa. These two receptor types exhibit pGC activity for cGMP production. By contrast, NPR-C receptors are disulfide-linked homodimer proteins of 60-70 kDa. These receptors do not possess GC activity, but do bind all endogenous NPs, thus facilitating the clearance of NP (27-30). The NPR subtypes have also been characterized with respect to their ligand selectivities and the potencies with which they stimulate cGMP production by activating $\mathrm{pGC}$; the relative potencies for NPR-A and NPR-B are ANP $>$ BNP $>>C N P$ and $\mathrm{CNP}>\mathrm{BNP}>\mathrm{ANP}$, respectively $(27,30,31)$. In addition, competition binding experiments have revealed that ANP and BNP exhibit greater affinities for ${ }^{125} \mathrm{I}-\mathrm{DNP}$ binding sites than $\mathrm{CNP}$ and C-ANP, at least in human heart tissue (7). Using CHO-K1 cells expressing human recombinant NPR subtypes, DNP was observed to have a high affinity for NPR-A type receptors and no affinity for NPR-B type receptors (32). High plasma levels of DNP have been previously detected and it has been demonstrated that DNP produced cGMP via the activation of NPR-A subtype receptors and that DNP exerts marked effects on renal function in rabbits $(8,9)$. In the present study, various natriuretic peptides, including DNP, ANP, BNP and CNP, were found to augment the production of cGMP via pGC in plasma membranes isolated from the renal glomeruli and inner medulla of rat kidneys. Furthermore, it was identified that natriuretic peptides ranked in the following order regarding their potency in stimulating cGMP production: $A N P \geq D N P \geq B N P>>C N P$. The extent to which NPR-A subtype receptors are modulated in STZ-induced diabetic rats was also evaluated. The responsiveness of DNP to the activities of pGC in the glomerular and inner medullary membranes of the kidney were compared. Notably, it was identified that DNP induced a dose-dependent increase in the cGMP response in the glomerular membranes of STZ-induced diabetic rats, whereas the cGMP responses in the inner medullary membranes were decreased compared with the control rats. Therefore, the present results indicated that NPR-A subtype receptors are the predominant type of DNP receptor of all the GC-coupled NPRs in the rat kidney. These receptors can be upregulated in the kidney glomeruli of STZ-induced diabetic rats.

In conclusion, the present study demonstrated several properties of STZ-induced diabetic rats. Their plasma DNP levels were significantly elevated compared with the control rats and did not correlate with any increases in cardiac and/ or renal DNP levels. The specific ${ }^{125}$ I-DNP binding sites in their kidneys were localized predominantly in the glomeruli and the inner medulla and the maximum binding capacities of ${ }^{125} \mathrm{I}$-DNP to their glomeruli were significantly increased compared with the control rats. The potency rank order of the NPR subtypes in the kidney regarding cGMP production was $A N P \geq D N P \geq B N P>>C N P$. Furthermore, DNP stimulated a dose-dependent response in the production of cGMP, which was enhanced in the glomeruli of diabetic rats compared with the control rats. Finally, thedaily urination volumes and urinary electrolyte excretions were significantly increased compared with the control rats.

These findings suggested that DNP and its receptor system modulate certain mechanisms of glomerular hyperfiltration by upregulating the DNP-NPR-A-pGC-cGMP signaling pathway, at least in animal models of diabetes.

\section{Acknowledgements}

The authors would like to thank Mrs. Robin Skowron and Mrs. Do Park for proofreading the manuscript. This study was supported by research funds from Chonbuk National University in 2011 and the Basic Science Research Program through the National Research Foundation of Korea, funded by the Ministry of Education, Science and Technology (grant no. 20110014864) and the Korean government (MSIP; grant no. 2008-0062279).

\section{References}

1. Schweitz H, Vigne P, Moinier D, Frelin C and Lazdunski M: A new member of the natriuretic peptide family is present in the venom of the green mamba (Dendroaspis angusticeps). J Biol Chem 267: 13928-13932, 1992.

2. Schirger JA, Heublein DM, Chen HH, et al: Presence of Dendroaspis natriuretic peptide-like immunoreactivity in human plasma and its increase during human heart failure. Mayo Clin Proc 74: 126-130, 1999.

3. Lisy O, Lainchbury JG, Leskinen $\mathrm{H}$ and Burnett JC Jr: Therapeutic actions of a new synthetic vasoactive and natriuretic peptide, dendroaspis natriuretic peptide, in experimental severe congestive heart failure. Hypertension 37: 1089-1094, 2001

4. Woodard GE, Rosado JA and Brown J: Dendroaspis natriuretic peptide-like immunoreactivity and its regulation in rat aortic vascular smooth muscle. Peptides 23: 23-29, 2002.

5. Chen HH, Lainchbury JG and Burnett JC: Natriuretic peptide receptors and neutral endopeptidase in mediating the renal actions of a new therapeutic synthetic natriuretic peptide dendroaspis natriuretic peptide. J Am Coll Cardiol 40: 1186-1191, 2002.

6. Lainchbury JG, Lisy O, Burnett JC Jr, Meyer DM and Redfield MM: Actions of a novel synthetic natriuretic peptide on hemodynamics and ventricular function in the dog. Am J Physiol 282: R993-R998, 2002.

7. Singh G, Kuc RE, Maguire JJ, Fidock M and Davenport AP: Novel snake venom ligand dendroaspis natriuretic peptide is selective for natriuretic peptide receptor-A in human heart: downregulation of natriuretic peptide receptor-A in heart failure. Circ Res 99: 183-190, 2006.

8. Kim SM, Kim YA, Kim SY, Kim SH, Cho KW and Kim SZ: Presence of dendroaspis natriuretic peptide and its binding to NPR-A receptor in rabbit kidney. Regulatory peptides 167 : 42-49, 2011.

9. Kim SM, Kim SY, Kim SH, Cho KW and Kim SZ: Renal actions of dendroaspis natriuretic peptide in rabbits. Peptides 33: 59-66, 2012.

10. Kim SM, Kim SY, Kim SH and Kim SZ: Dendroaspis natriuretic peptide is degraded by a metalloproteinase in the rat kidney. Mol Med Rep 9: 1037-1043, 2014.

11. Dronavalli S, Duka I, and Bakris GL: The pathogenesis of diabetic nepthropathy. Nat Clin Pract Endocrinol Metab 4: 444-452, 2008

12. Walther T, Heringer-Walther S, Tschope R, Reinecke A, Schultheiss HP and Tschope C: Opposite regulation of brain and C-type natriuretic peptides in the streptozotocin-diabetic cardiopathy. J Mol Endocrinol 24: 391-395, 2000. 
13. Obineche EN, Adeghate E, Chandranath IS, Benedict S, Al Gafri LS and Adem A: Alterations in atrial natriuretic peptide and its receptors in streptozotocin-induced diabetic rat kidneys. Mol Cell Biochem 261: 3-8, 2004.

14. Ortola FV, Ballermann BJ, Anderson S, Mendez RE and Brenner BM: Elevated plasma atrial natriuretic peptide levels in diabetic rats. Potential mediator of hyperfiltration. J Clin Invest 80: 670-674, 1987.

15. Jacobs EM, Vervoort G, Branten AJ, Klasen I, Smits P and Wetzels JF: Atrial natriuretic peptide increases albuminuria in type I diabetic patients: evidence for blockade of tubular protein reabsorption. Eur J Clin Invest 29: 109-115, 1999.

16. Sawicki PT, Heinemann L, Rave K, Hohmann A and Berger M: Atrial natriuretic factor in various stages of diabetic nephropathy. J Diabet Complications 2: 207-209, 1988.

17. Benigni A, Perico N, Dadan J, et al: Functional implications of decreased renal cortical atrial natriuretic peptide binding in experimental diabetes. Circ Res 66: 1453-1460, 1990.

18. Sechi LA, Valentin JP, Griffin CA, et al: Receptors for atrial natriuretic peptide are decreased in the kidney of rats with streptozotocin-induced diabetes mellitus. J Clin Invest 95: 2451-2457, 1995.

19. Christoffersen C, Bartels ED and Nielsen LB: Heart specific up-regulation of genes for B-type and C-type natriuretic peptide receptors in diabetic mice. European journal of clinical investigation 36: 69-75, 2006.

20. Cho KW, Kim SH, Kim CH and Seul KH: Mechanical basis of ANP secretion in beating atria: atrial stroke volume and ECF translocation. Am J Physiol 268: R1129-R1136, 1995.

21. Kim SZ, Cho KW and Kim SH: Modulation of endocardial natriuretic peptide receptors in right ventricular hypertrophy. Am J Physiol 277: H2280-H2289, 1999.

22. Kim SZ, Kim SH, Park JK, Koh GY and Cho KW: Presence and biological activity of C-type natriuretic peptide-dependent guanylate cyclase-coupled receptor in the penile corpus cavernosum. J Urol 159: 1741-1746, 1998.
23. Munson PJ and Rodbard D: Ligand: a versatile computerized approach for characterization of ligand-binding systems. Anal Biochem 107: 220-239, 1980

24. Wu YS, Lu HL, Huang X, Liu DH, Meng XM, Guo X, Kim YC, and Xu WX: Diabetes-induced loss of gastric ICC accompanied by up-regulation of natriuretic peptide signaling pathways in STZ-induced diabetic mice. Peptides 40: 104-111, 2013

25. Wu SQ, Kwan CY and Tang F: Streptozotocin-induced diabetes has differential effects on atrial natriuretic peptide synthesis in the rat atrium and ventricle: a study by solution-hybridization-RNase protection assay. Diabetologia 41: 660-665, 1998.

26. Bai GY, Piao FL, Kim SY, Yuan K, Kim SZ and Kim SH: Augmentation of insulin-stimulated ANP release through tyrosine kinase and PI 3-kinase in diabetic rats. Peptides 27: 2756-2763, 2006.

27. Chinkers M, Garbers DL, Chang MS, et al: A membrane form of guanylate cyclase is an atrial natriuretic peptide receptor. Nature 338: 78-83, 1989.

28. Porter JG, Wang Y, Schwartz K, et al: Characterization of the atrial natriuretic peptide clearance receptor using a vaccinia virus expression vector. J Biol Chem 263: 18827-18833, 1988.

29. Maack T, Suzuki M, Almeida FA, et al: Physiological role of silent receptors of atrial natriuretic factor. Science 238: 675-678, 1987.

30. Koller KJ, Lowe DG, Bennett GL, et al: Selective activation of the B natriuretic peptide receptor by C-type natriuretic peptide (CNP). Science (New York, N.Y.) 252: 120-123, 1991.

31. Suga S, Nakao K, Hosoda K, et al: Receptor selectivity of natriuretic peptide family, atrial natriuretic peptide, brain natriuretic peptide, and C-type natriuretic peptide. Endocrinology 130: 229-239, 1992.

32. Johns DG, Ao Z, Heidrich BJ, et al: Dendroaspis natriuretic peptide binds to the natriuretic peptide clearance receptor. Biochem Biophys Res Commun 358: 145-149, 2007. 